\title{
Activity Determination, Kinetic Analyses and Isoenzyme Identification of Gamma Glutamyltransferase in Human Neutrophils
}

\author{
Azize Sener* and Turay Yardimci \\ Department of Biochemistry, Faculty of Pharmacy, Marmara University, Tibbiye Cad., No.49, 34668, Haydarpasa-Istanbul, Turkdy
}

Received 5 October 2004, Accepted 8 January 2005

\begin{abstract}
Gamma-glutamyltransferase (GGT, EC 2.3.2.2) which hydrolyzes glutathione (GSH), is required for the maintenance of normal intracellular GSH concentration. GGT is a membrane enzyme present in leukocytes and platelets. Its activity has also been observed in human neutrophils. In this study, GGT was purified from Triton X-100 solubilized neutrophils and its kinetic parameters were determined. For kinetic analyses of transpeptidation reaction, $\gamma$-glutamyl $p$-nitroanilide was used as the substrate and glycylglycine as the acceptor. Apparent $K_{m}$ values were determined as $1.8 \mathrm{mM}$ for $\gamma$-glutamyl $p$ nitroanilide and $16.9 \mathrm{mM}$ for glycylglycine. The optimum pH of GGT activity was 8.2 and the optimum temperature was $37^{\circ} \mathrm{C}$. It had thermal stability with $58 \%$ relative activity at $56^{\circ} \mathrm{C}$ for $30 \mathrm{~min}$ incubation. L-serine, in the presence of borate, was detected as the competetive inhibitor. Bromcresol green inhibited neutrophil GGT activity as a noncompetetive inhibitor. The neutrophils seem to contain only the isoenzyme that is present in platelets. We characterized the kinetic properties and compared the type of the isoenzyme of neutrophil GGT with platelet GGT via polyacrylamide gel electrophoresis (PAGE) under a standart set of conditions.
\end{abstract}

Keywords: Gamma-glutamyltransferase, Isoenzyme, Kinetics, Neutrophils

\section{Introduction}

The ectoenzyme gamma-glutamyltransferase (GGT, 2.3.2.2) is one of the key enzymes in the gamma glutamyl cycle (Meister and Anderson, 1983) that catalyses the hydrolysis of gammaglutamyl compounds and transfer of amino acids or peptides.

*To whom correspondence should be addressed.

Tel: 90-216- 4492303; Fax: 90-216-4492303

E-mail: azizesener@hotmail.com
Gamma-glutamyl cycle involving GGT is generally thought to be the major pathway by which cells utilize extracellular GSH for de novo synthesis of intracellular GSH (Griffith et al., 1978). GGT was reported to be involved in the regulation of the level of glutathione (Meister, 1973), the metabolism of endogenous compounds like prostaglandins and the conversion of leukotriene $\mathrm{C}_{4}$ to leukotriene $\mathrm{D}_{4}$ (Ahorony, 1984; Pace-Asciak et al., 1986). Recently, it has been reported that GGT cleavage of GSH and subsequent recapture of cysteine and cystine allow cells to maintain low levels of cellular reactive oxygen species (ROS) and to avoid apoptosis induced by oxidative stress (Karp et al., 2001).

GGT has been demonstrated in various human and animal organs, including kidneys, liver and spleen. It is also present in various body fluids, such as saliva, serum, bile and urine (Nemesanzky and Lott, 1985; Sener, 1997). GGT has been detected both in blood and bone marrow cells by using cytochemical methods (Szmigielski et al., 1965). It has been demonstrated at the ultrastructural level on the surface membrane and membranes of endoplasmic reticulum and golgi apparatus of human lymphoid cells (Marathe et al., 1980). Girino et al. (1985) have demonstrated the existence of the enzyme in almost all normal leukocytes and in platelets at cytochemical level. In another study, it has been reported that GGT could serve as a differentiation marker in the study of granulocytic and lymphocytic cell lineages (Khalaf and Hayhoe, 1987).

GGT activity has also been observed in populations of nonstimulated mononuclear cells of human peripheral blood. The highest activities of GGT have been found in monocytes. Different activities have been observed in CD4 positive and CD8 positive $\mathrm{T}$ lymphocytes. It has been demonstrated that these differences might reflect different biochemical capacities of these cell types, related to their distinct functions in the immune system (Grisk et al., 1993). Recently It has been shown that resting peripheral blood $\mathrm{T}$ cells express a higher level of GGT than native T cells (Karp et al., 1999).

In our previous study, we both investigated the kinetic properties of GGT in platelets and demonstrated that there was 
only one GGT isoenzyme in human platelets (Yardimci et al., 1995; Sener and Yardimci, 2000).

In the present work, we have investigated the catalytic activity, kinetics properties, inhibitor effects, optimum $\mathrm{pH}$, optimum temperature and thermal stability of human neutrophil GGT. At the same time, neutrophil GGT isoenzyme was compared with platelet GGT isoenzyme on PAGE.

\section{Materials and Methods}

Materials Gamma-glutamyl p-nitroanilide, glycylglycine, Triton X-100, Con A Sepharose 4B (Ricinus Communis I), methyl $\alpha$-Dmannopyranoside, naphtylethylene diamine, dextrane, L-serine, bromcresol green and ficoll hypaque were purchased from Sigma Chemical Co. (St Louis, USA). Other chemicals were of reagent grade from Merck (Darmstadt, Germany).

Isolation of neutrophils Blood was drawn from normal human volunteers and anticoagulated with $0.077 \mathrm{M}$ EDTA (1:9 ratio). Neutrophils were isolated from plasma containing leukocytes and platelets by dextran sedimentation followed by Ficoll hypaque gradient centrifugation (Boyum, 1968). The residual red blood cells were lysed by hypotonic saline at $4{ }^{\circ} \mathrm{C}$ and the purified neutrophils were resuspended in phosphate buffered saline (PBS, $125 \mathrm{mM}$ $\mathrm{NaCl}, 8 \mathrm{mM} \mathrm{NaH} \mathrm{PO}_{4}, 5 \mathrm{mM} \mathrm{KCl}, 5 \mathrm{mM}$ glucose, $\mathrm{pH}$ 7.4) and stored on ice in $\mathrm{Ca}^{2+}$ and $\mathrm{Mg}^{2+}$ free medium. The final preparation contained more than $90 \%-95 \%$ neutrophils. The isolated neutrophils were washed three times in PBS and concentrated to $5 \times 10^{6}$ cells per $\mathrm{ml}$ in PBS containing $1 \%$ Triton X-100. Then, the cells were left standing for $5 \mathrm{~h}$, with gently stirred and centrifuged at $10.000 \mathrm{rpm}$ for $15 \mathrm{~min}$ at $4^{\circ} \mathrm{C}$ to give a clear supernatant.

Gamma-glutamyltransferase assay The GGT activity was determined by the hydrolysis of g-glutamyl p-nitroanilide in the presence of the acceptor glycylglycine (Szasz, 1969). Standard assay included final reagent concentrations $4 \mathrm{mM}$ of $\gamma$-glutamyl $p$ nitroanilide, $40 \mathrm{mM}$ of glycylglycine and $185 \mathrm{mM}$ of Tris- $\mathrm{HCl}, \mathrm{pH}$ 8.2. The rate of p-nitroaniline formation was measured at $405 \mathrm{~nm}$ by using spectrophotometer. The results were expressed as pkat per $10^{6}$ neutrophils using milimolar absorptivity of 9.900 . One katal of activity is defined as amount of enzyme that will catalyze the formation of one mole of p-nitroaniline per second under the conditions of the assay procedure. Serum GGT activity was expressed as U/L. One Unit of enzyme represents the amount of enzyme that catalyzes the release of $1 \mathrm{mmol}$ of nitroaniline $/ \mathrm{min}$. The assay was used in all steps of the isolation of neutrophil GGT and kinetic studies. Protein levels were determined according to the method of Bradford (1976) using bovine serum albumin as the standard.

Purification of neutrophil GGT The method of Vesely et al. (1985) was used with some modifications. Triton X-100 solubilized neutrophil fractions from nine subjects were first pooled and then precipitated with ammonium sulphate (45-90\% saturation). The precipitated proteins were dialyzed and chromatographed on a Sephadex G-200 column. Fractions containing GGT activities of the Sephadex G-200 were pooled and incubated for $3 \mathrm{~h}$ at $37^{\circ} \mathrm{C}$ with Con A Sepharose 4B. Con A Sepharose 4B was packed into a column $(0.9 \times 5 \mathrm{~cm})$ and washed with $10 \mathrm{mM}$ Tris $\mathrm{HCl}$ buffer containing $0.2 \%$ Triton $\mathrm{X}-100,0.5 \mathrm{M} \mathrm{NaCl}, 10 \mathrm{mM} \mathrm{MgCl}_{2}$ and 10 $\mathrm{mM} \mathrm{CaCl}_{2}$ until no protein could be eluted. Then, the bound protein was eluted with the same buffer containing $0.3 \mathrm{M}$ methyl $\alpha$-Dmannopyranoside.

Kinetic studies of neutrophils Transpeptidation reaction of GGT examined between two substrates. The $K_{m}$ and $V_{\max }$ estimated at fixed set of cosubstrate concentrations is not the true values but rather apparent values. Therefore these parameters are referred as apparent $K_{m}$, apparent $V_{\max }$.

The GGT activity was measured at various concentrations (1-10 $\mathrm{mM})$ of the substrate $\gamma$-glutamyl p-nitroanilide and $40 \mathrm{mM}$ glycylglycine as the acceptor at $37^{\circ} \mathrm{C}$ at $\mathrm{pH} 8.2$ for transpeptidation reaction. All of the experiments were performed in duplicates. Apparent $K_{m}$ and apparent $V_{\text {max }}$ values were determined from Lineweaver Burk plots for $\gamma$-glutamyl $p$-nitroanilide. Concentration of the acceptor glycylglycine for determination of apparent $K_{m}$ and apparent $V_{\max }$ values varied between $10-100 \mathrm{mM}$, and $\gamma$-glutamyl $p$ nitroanilide concentration was $4 \mathrm{mM}$ at $37^{\circ} \mathrm{C}$ at $\mathrm{pH} 8.2$.

Determination of optimum temperature and optimum $\mathrm{pH}$ The neutrophil GGT was incubated at $56^{\circ} \mathrm{C}$ at different time periods (5$30 \mathrm{~min}$ ) keeping all other variables constant for the thermal stability determination. For optimum temperature detection, the GGT activities were determined after incubation for $1 \mathrm{~min}$ and $10 \mathrm{~min}$ at different temperatures $\left(25-56^{\circ} \mathrm{C}\right)$. The reaction mixture contained 4 mmol of $\gamma$-glutamyl p-nitroanilide per $\mathrm{L}$ and $40 \mathrm{mM}$ of glycylglycine per L.

Enzyme activity was followed with respect to $\mathrm{pH}$ variations using Tris-HCl buffer ( $\mathrm{pH} 5-7$ ) and phosphate buffer ( $\mathrm{pH}$ 8-9) containing $4 \mathrm{mmol}$ of $\gamma$-glutamyl $p$-nitroanilide per $\mathrm{L}$ and $40 \mathrm{mmol}$ of glycylglycine per L.

Inhibition studies The GGT inhibition with L-serine-borate mixture and with bromcresol green was studied by using Tris- $\mathrm{HCl}$ buffer containing various concentrations of $\gamma$-glutamyl $p$ nitroanilide (1-10 $\mathrm{mM})$ and $40 \mathrm{mmol}$ of glycylglycine per L. Lserine $(2.5 \mathrm{mM})$ and borate $(10 \mathrm{mM})$ were added to the reaction mixtures. Bromcresol green concentration was $0.01 \mathrm{mM}$. The GGT activities were assayed after $1 \mathrm{~min}$ incubation with the inhibitors.

Detecting the enzyme activities on gels Neutrophil GGT, purified by Con A Sepharose 4B column chromatograpy, was electrophoresed in polyacrylamide gels $(7.5 \%)$ according to the method of Davis (1964) with Tris-glycine buffer ( $\mathrm{pH} 8.3$ ). The GGT staining was performed as described by Selveraj and Balasubramanian (1982). Gels, soon after polyacrylamide gel electrophoresis (PAGE), were immersed in a staining solution containing $185 \mathrm{mM}$ Tris- $\mathrm{HCl}, 4 \mathrm{mM} \gamma$-glutamyl $p$-nitroanilide, 80 $\mathrm{mM}$ glycylglycine, $0.1 \%$ sodium nitrite and $0.4 \%$ naphtyl ethylenediamine dihydrochloride $(\mathrm{pH} 8.2)$ and incubated at $37^{\circ} \mathrm{C}$ for $30 \mathrm{~min}$. The gels were then washed with $10 \mathrm{mM}$ Tris- $\mathrm{HCl}(\mathrm{pH}$ 8.9) and transferred to cold $0.38 \mathrm{mM}$ trichloroacetic acid. Within 10 min, a pink band appeared on the gels in the region of GGT. Protein staining was accomplished with Commasie Brillant Blue R-250. 


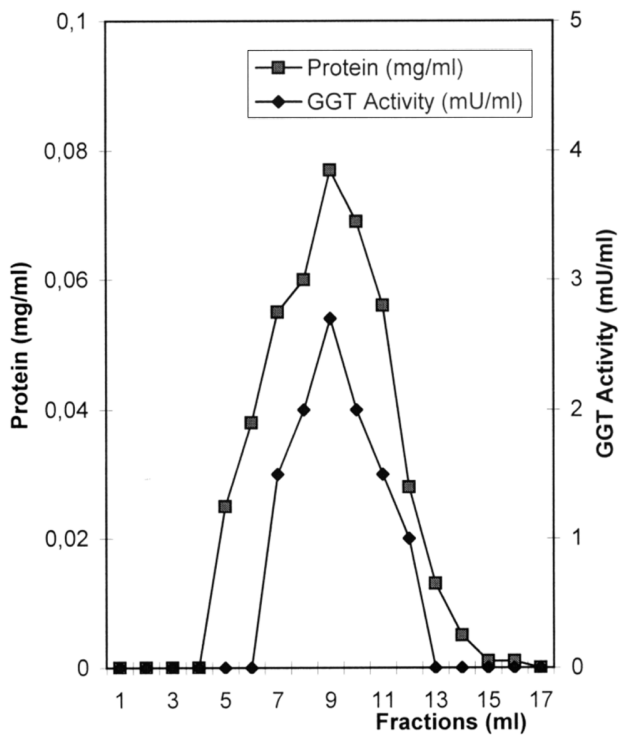

Fig. 1. Elution profile of Con $A$ sepharose $4 B$ column chromatography $(0.9 \times 5 \mathrm{~cm})$ in $10 \mathrm{mM}$ Tris $\mathrm{HCl}$ buffer $(\mathrm{pH} 8.2)$ containing $0.2 \%$ Triton $\mathrm{X}-100,0.5 \mathrm{M} \mathrm{NaCl}, 10 \mathrm{mM} \mathrm{MgCl}_{2}, 10$ $\mathrm{mM} \mathrm{CaCl}$ and $0.3 \mathrm{M}$ methyl $\alpha$-D-mannopyranoside.

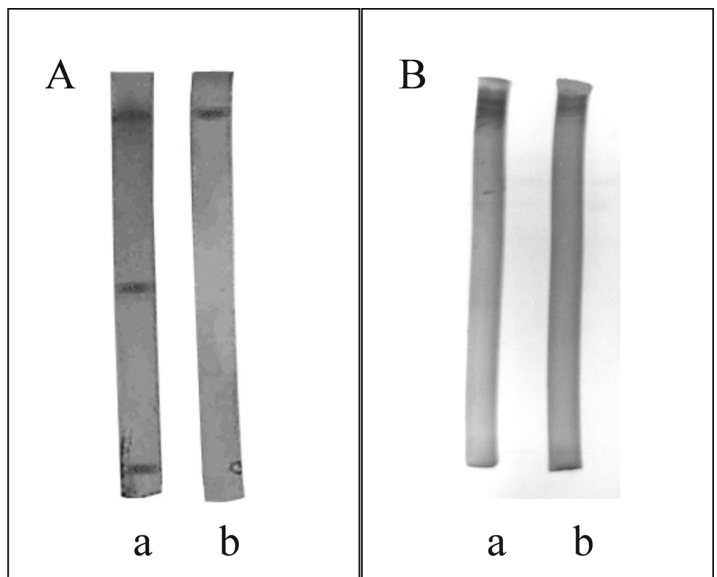

Fig. 2. (A) The results of PAGE with protein stainning (a, Triton X-100 solubilized proteins of human neutrophils, b, Purified human neutrophile GGT) (B) Gels of GGT specific staining (a, Human platelet GGT, b, Human neutrophile GGT).

\section{Results}

The GGT activities of Triton X-100 solubilized neutrophils from nine healthy subjects between 20-30 years of age were determined. The median neutrophil GGT activity and the serum GGT activity were $6.2 \pm 1.3$ pkat $/ 10^{6}$ neutrophils and $13 \pm 3 \mathrm{U} / \mathrm{L}$ respectively.

Solubilized fractions with Triton X-100 of nine subjects (their GGT activities varying between $5.0-8.0 \mathrm{pkat} / 10^{6}$ neutrophils) were pooled and used for purification. The human neutrophil GGT was purified by lectin affinity chromatography on Con A Sepharose 4B. The specific

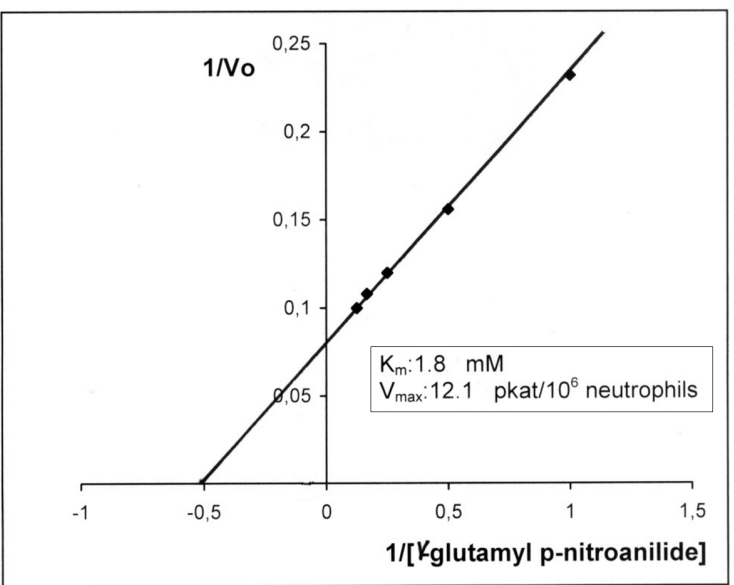

Fig. 3. Lineweaver Burk plot for human neutrophile GGT with $\gamma$-glutamyl $p$-nitroanilide as substrate. The reaction mixture contained $185 \mathrm{mM}$ Tris-HCl buffer (pH: 8.2 ), $40 \mathrm{mM}$ glcylglycine and varying concentrations of $\gamma$-glutamyl $p$-nitroanilide.

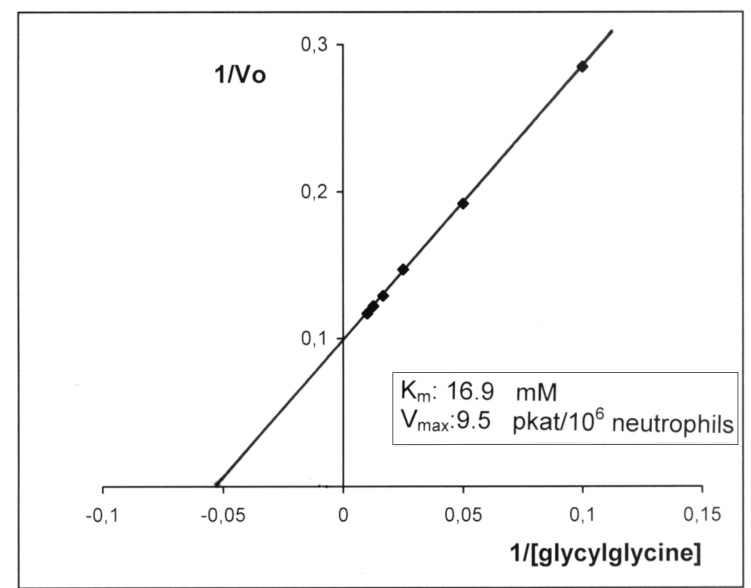

Fig. 4. Lineweaver Burk plot for human neutrophile GGT with glcylglycine as acceptor. The reaction mixture contained 185 $\mathrm{mM}$ Tris- $\mathrm{HCl}$ buffer ( $\mathrm{pH}: 8.2$ ), $4 \mathrm{mM}$ g-glutamyl $p$-nitroanilide and varying concentrations of glcylglycine.

activity of purified GGT was $31.3 \mathrm{mU} / \mathrm{mg}$ protein. In Fig. 1, the Con A Sepharose 4B column chromatography elution profile is shown. The fractions with high specific activities were pooled. When PAGE was applied to the purified GGT from Triton X-100 solubilized neutrophiles, a single protein band was observed. It was shown that there was only one GGT isoenzyme in neutrophils with GGT staining on the PAGE. It was observed that the electrophilic mobility of this protein had the same electrophilic mobility with the platelet GGT isoenzyme (Fig. 2).

The Lineweaver Burk plots of the $\gamma$-glutamyl $p$-nitroanilide concentration dependency of human neutrophil GGT of normal cases are seen in Fig. 3. The apparent $K_{m}$ and apparent $V_{\text {max }}$ values were calculated as $1.8 \mathrm{mM}$ and $12.1 \mathrm{pkat} / 10^{6}$ neutrophils. For acceptor glycylglycine, apparent $K_{m}$ and 


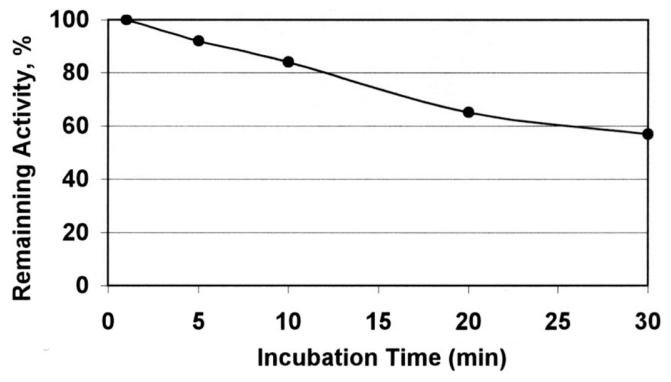

Fig. 5. Thermal stability of human neutrophile GGT activity at $56^{\circ} \mathrm{C}$.

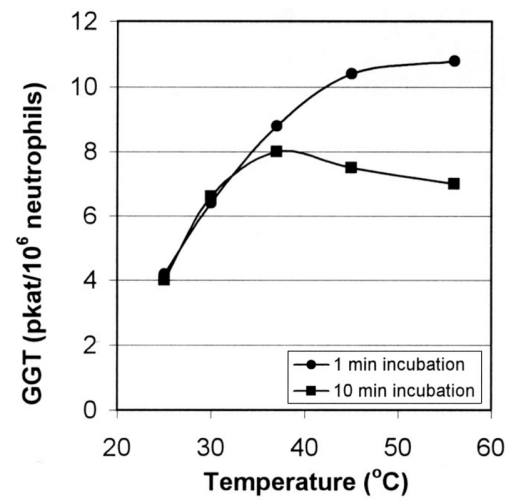

Fig. 6. Effect of temperature on neutrophile GGT activity.

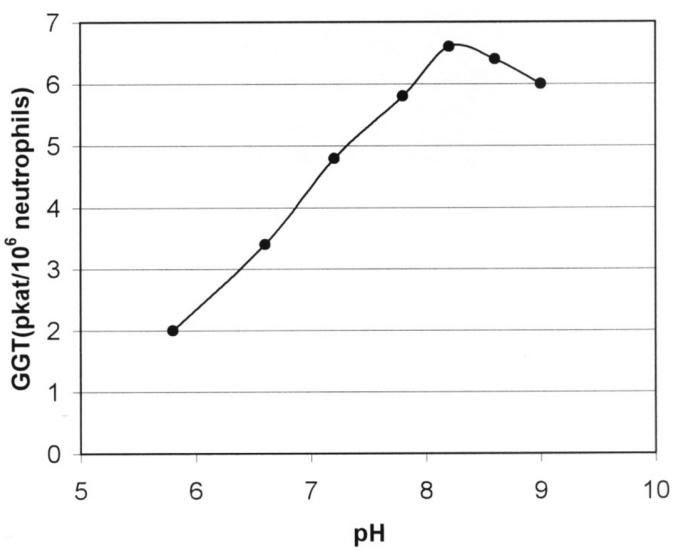

Fig. 7. Effect of pH on neutrophile GGT activity.

apparent $V_{\max }$ values were $16.9 \mathrm{mM}$ and $9.5 \mathrm{pkat} / 10^{6}$ neutrophils from Lineweaver Burk Plots (Fig. 4).

When the enzyme was heated at $56^{\circ} \mathrm{C}$ for varying periods, the neutrophil GGT, like platelet GGT, had high thermal stability. $58 \%$ of relative activity remained after $30 \mathrm{~min}$ incubation at $56^{\circ} \mathrm{C}$ (Fig. 5). The optimum temperature was determined to be $37^{\circ} \mathrm{C}$ (Fig. 6), and the optimum $\mathrm{pH}$ was 8.2 (Fig. 7), when $4 \mathrm{mM} \gamma$-glutamyl p-nitroanilide was used as the substrate and $40 \mathrm{mM}$ glycylglycine as the acceptor.

In the presence of borate $(10 \mathrm{mM})$, L-serine $(2.5 \mathrm{mM})$ competitively inhibited $32 \%$ of the neutrophile GGT activity at $4 \mathrm{mM}$ concentration of $\gamma$-glutamyl p-nitroanilide (Fig. 8).

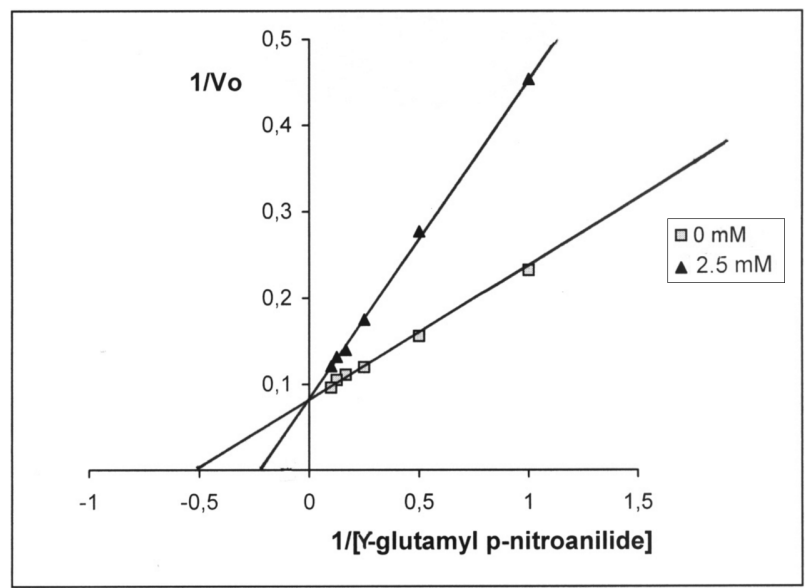

Fig. 8. Lineweaver Burk plot of L-serine $(2.5 \mathrm{mM})$ inhibition on the activity of neutrophile GGT at $37^{\circ} \mathrm{C}$ in the presence of 10 $\mathrm{mmol} / \mathrm{L}$ borate.

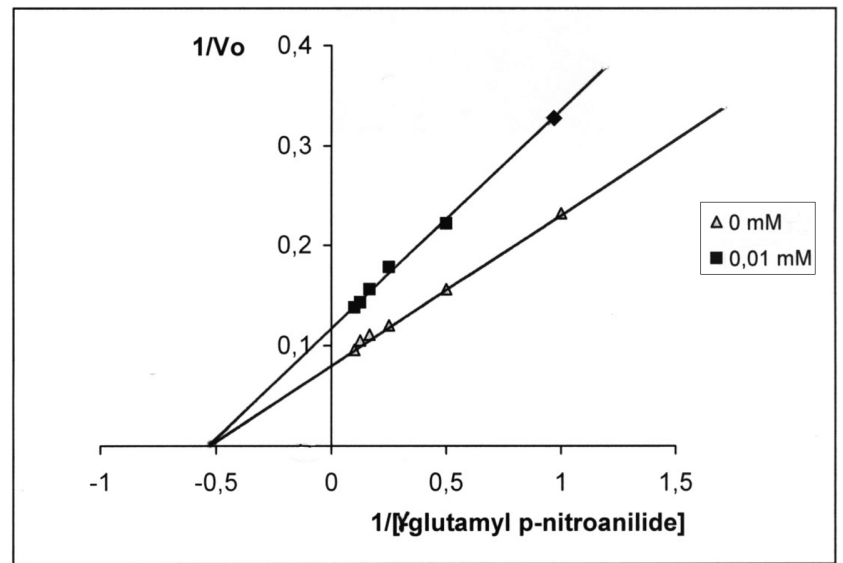

Fig. 9. Lineweaver Burk plot of bromcresol green $(0.01 \mathrm{mM})$ inhibition on the activity of neutrophile GGT at $37^{\circ} \mathrm{C}$.

Inhibition of enzyme activity by Bromcresol green $(0.01 \mathrm{mM})$ caused $31 \%$ inhibition at $4 \mathrm{mM}$ concentration of $\gamma$-glutamyl $p$ nitroanilide. This inhibition was noncompetitive inhibition as determined from Lineweaver Burk Plots (Fig. 9).

\section{Discussion}

GGT is a heterodimeric glycoprotein anchored to the outside surface of the plasma membrane of both animal and plant cells (Abbott et al., 1982). GGT can be solubilized by using detergents such as TritonX-100 and deoxycholate or by treatment with proteinases (e.g. papain). Detergents solubilized the entire molecule, whereas proteinases cleave the hydrophilic active site containing the domain from the membrane bound anchor (Nemesanzky and Lott, 1985). We also observed that papain solubilized GGT had a higher mobility than Triton X-100 solubilized GGT. This difference are related to the amino acid chain length (Sener and 
Yardimci, 2000).

Species and tissue differences were described in terms of the GGT affinity to Con A lectin (Goldstein et al., 1965; Shaw et al., 1978; Dvorakova et al., 1992). It is reported that differences in Con A binding properties cannot be related structures (Dvorakova et al., 1992b). However, after neuraminidase treatment, reduction in Con A binding, dependent on sialic acid content, has been reported (Delanghe et al., 1987). In our previous work, the incubation of platelet GGT with Con A sepharose resulted in the binding of $73 \%$ of the activity to gel (Sener and Yardimci, 2000).

The GGT isoenzyme bands are characterized by their relationship with the major serum protein fractions. Normal serum GGT has been separeted in two fractions, namely $\alpha_{1}$ globulin and $\alpha_{2}$-globulin by cellulose acetate electrophoresis (Burlina, 1978). Increased serum levels and isoenzyme patterns of GGT has been noted in some pathological conditions such as liver, biliary tract disorders and pancreatic diseases. Four GGT isoenzymes that were named as GGT1, GGT2, GGT3 and GGT4 were determined in albumin, $\alpha_{1}-$ globulin, $\alpha_{2}$-globulin and $\beta$-globulin fractions respectively (Burlina, 1978, Nemesanzky and Lott, 1985). The electrophoretic heterogenity of the GGT isoenzymes in serum was reported to be due to post-translational modification (Nemesanzky and Lott, 1985). However, Pawlak et al. (1988) showed that at least four genes containing GGT sequences were present in the human genome. These are located at band q11 on chromosome 22 (Morris et al., 1993; Collins et al., 1997). Recently, It has been reported that the human GGT was encoded by a multigene family including at least seven genes. These genes have not fully characterized. Only one of genes (gene I) was found functional and produced multiple transcripts that were translated into complete and functional proteins. In human, This gene codes least three 5 ' altering mRNAs (Chikhi et al., 1999). It has been suggested that human GGT gene employs regulatory sequences and alternative splicing (Visvikis et al., 2001). Therefore, isoenzymes of GGT may be related tissue specific expression. In our previous work, we showed that human platelets contained only one isoenzyme (Sener and Yardimci, 2000). Gürdöl et al. (1995) also reported that human platelets contained one isoenzyme, GGT 4.

In the study with serum GGT, it was reported that for $\gamma$ glutamyl $p$-nitroanilide and glycyl glycine, the $K_{m}$ values were $1.9 \mathrm{mM}$ and $12.0 \mathrm{mM}$ respectively (Rosalki and Tarlow, 1974). We have shown that for $\gamma$-glutamyl p-nitroanilide and glycyl glycine, in the platelets of normal subjects, the $K_{m}$ values were calculated as $2.1 \mathrm{mM}$ and $15.9 \mathrm{mM}$ respectively (Yardimci et al, 1995). It was reported in the literature that in human brain capillaries, the partially purified GGT had optimum pH between 8.2 and 9 (Vesely et al., 1985). The $K_{m}$ value of human liver GGT, when $\gamma$-glutamyl $p$-nitroanilide was used as the substrate, was reported as $1.4 \mathrm{mM}$, and for kidney it was $1.2 \mathrm{mM}$. For glycylglycine, the $K_{m}$ value was $10.6 \mathrm{mM}$ for the liver and 10.7 the $\mathrm{mM}$ for kidneys (Shaw et al., 1978).

L-serine against borate and bromcresol green are widely used inhibitors of GGT in kinetic studies. L-serine inhibits GGT in the presence of borate by interacting with the $\gamma$ glutamyl binding site of the enzyme (Tate and Meister, 1978; Vesely et al., 1985). Purified rat deciduoma had an optimum $\mathrm{pH}$ of 8.2 and a $K_{m}$ value of $1 \mathrm{mM}$ for $\gamma$-glutamyl $p$-nitroanilide and $7.6 \mathrm{mM}$ for glycylglycine. L-serine, in presence borate, inhibited GGT competetively, $\mathrm{K}_{\mathrm{i}}$ being $22 \mu \mathrm{M}$ (Taracand, 1984).

Brom cresol green inhibited neutrophil GGT noncompotetively whereas in presence of borate, L-serine inhibited competetively. The neutrophil GGT kinetics showed similarities with platelet GGT and some differences from $K_{m}$ value of $\gamma$-glutamyl $p$ nitroanilide in other tissues. We think that the differences are related to different isoenzyme.

Gamma-glutamyltransferase was also found as a membrane enzyme in immune cells using immunocytochemical and biochemical methods (Khalaf and Hayhoe, 1987). Investigations showed activity in almost all bone marrow and blood cells, but it was weaker in these cells. The GGT activities were found $7.3-20.0 \mathrm{pkat} / 10^{6}$ cells in monocytes (Grisk et al., 1993).

Primary human memory $\mathrm{T}$ cells express higher level of GGT than native $T$ cells. It has been suggested that GGT might play an important role in the regulation of lymphocytes which are at a particular developmental stage (Karp et al.,1999). At the same time, GGT expression, highly sensitive to oxidative stress, is a part of the cell antioxidant defence mechanisms (Karp et al., 2001).

GGT activity is increased in a number of primary and metastatic tumors (Dominici et al., 2003). It has been shown that hepatocellular carcinoma can be expressed hepatoma specific GGT and secreted GGT in to circulating blood (Yao et al., 1998). Beltran-Martinez and Correa-Chacon (2003) suggested that GGT was a useful marker of metastatic disease in patients with renal cell carcinoma. GGT activity also changes several types of lekuemia (Tager et al., 1995). Novogrodsky et al. (1976) indicated that GGT is lymphoid cell surface marker reflecting differantiation in normal and malignant cells. The GGT activity of blood lymphoid cells of normals and Acute Lymphoblastic Leukemia (ALL) were determined as $2.3 \pm 0.3 \mathrm{U} / \mathrm{mg}$ protein and $1.1 \pm 0.2 \mathrm{U} / \mathrm{mg}$ protein respectively (Russo et al., 1987). By contrast, it was reported that GGT levels increased in acute myeloid leukemia, chronic myeloid leukemia and high grade non Hodgkins lymphoma (Antczak et al., 2001).

In our studies, the kinetics of GGT is described in human neutrophil. The differences in our results, when compared with other tissues, might be due to the presence of different isoenzymes. The optimum $\mathrm{pH}$ and temperature values of neutrophils were similar to other cells, as reported in the literature. We have showed that human neutrophils contains a GGT isoenzyme similar to the platelet isoenzyme. These studies may contribute to the use of GGT in diagnosis and 
prognosis of various haematological disorders and to understand the function of GGT in leukocytes.

Acknowledgments This work was supported by Marmara University Research Foundation (Project No. 43).

\section{References}

Abbott, W. A., Griffith, O. W. and Meister, A (1986) $\gamma$-glutamyl glutathione. Natural occurrence and enzymology. J. Biol. Chem. 261, 13657-13661.

Ahorony, D. (1984) Discriminative effect of ã-GT inhibitor on metabolism of leukotriene C4 in peritoneal cells. Life. Sci. 35, 2135-2142.

Antczak, C., De Meester, I. and Bauvois, B. (2001) Transmembrane proteases as disease markers and targets for therapy. J. Biol. Regul. Homeost. Agents 15, 130-139.

Boyum, A. (1968) Isolation of mononuclear cells and granulocytes from human blood. Scand. Clin. Lab. Invest. 21, 77-89.

Bradford, M. M. (1976). A rapid and sensitive method for the quantitation of microgram quantities of protein utilizing the principle of protein dye binding. Anal. Biochem. 72, 248-254.

Beltran-Martinez, R. J. and Correa-Chacon, A. J. (2003) Diagnostic value of gamma-glutamyltransferase in the metastatic disease of patients with renal cell carcinoma. Gac. Med. Mex. 139, 123-125.

Burlina, A. (1978) Improved method for fractionating $\gamma$-glutamyl transferase by electrophoresis on cellulose acetate. Clin. Chem. 24, 502-504.

Chikhi, N., Holic, N., Guellaen, G. and Laperche, Y. (1999) Gamma-glutamyl transpeptidase gene organization and expression: a comparative analysis in rat mouse, pig and human species. Comp. Biochem. Physiol. Part B Biochem. Mol. Biol. 122, 367-380.

Collins, J. E., Mungall, A. J., Badcock, K. L., Fay, J. N. and Dunham, I. (1997) The organization of $\gamma$-glutamyltransferase genes and other low copy repeats in human chromosome 22q11. Genome Res. 7, 522-531.

Davis, B. J. (1964) Disc electrophoresis II. Method and application to human serum proteins. Ann. NY Acad Sci. 121, 404-409.

De Lange, J. R., De Buyzere, M. L., De Scheerder, I. K., Claeys, L. R. and Vieme, R. J. (1987) Lectin affinity chromatography of serum gglutamyltransferase in liver disease. Clin. Chem. Acta 162, 311-318.

Dominici, S., Pieri, L., Comporti, M. and Pompella, A. (2003) possible role of membrane gamma-glutamyltransferse activity in the facilitation of transferrin-dependent and independent iron uptake by cancer cells. Cancer Cell Int. 3, 7-15.

Dvorakova, L., Lisy, V. and Stastry, F. (1992a) Developmental changes in the activity of membrane bound gamma-glutamyl transpeptidase and in the sialylation of synaptosomal membranes from the chick embriyonic brain. J. Biochem. 203, 669-672.

Dvorakova, L., Lisy, V. and Stastry, F. (1992b) Fractionation of $\gamma$ glutamyl transpeptidase from the rat brain, kidney and pancreas by Concanavalin A affinity chromatography. Biochem. Int. 28, 957-964.
Girino, M., Invernizzi, R., Perseghin, P. and Michienzi, M. (1985) Cytochemical study of gamma-glutamyltranspeptidase activity in normal blood cells and in blood malignancyes. Hematologica. 70, 266-268.

Goldstein, I. J., Hollerman, C. E and Smith, E. R. (1965) Proteincarbohydrate interaction. II. Inhibition studies on the interaction of concanavalin A with polysaccharides. Biochemistry 4, 876883.

Griffith, O. W., Bridges, R. J. and Meister A (1978) Evidence that the $\gamma$-glutamyl cycle functions in vivo using intracellular glutathione: effects of amino acids and selective inhibition of enzymes. Proc. Natl. Acad. Sci. USA 75, 540-545.

Grisk, O., Küster, U. and Angorge, S. (1993) The activity of $\gamma$ glutamyl transpeptidase $(\gamma-\mathrm{GT})$ in populations of mononuclear cells from human peripheral blood. Biol. Chem. Hoppe-Seyler 374, 287-290.

Gürdöl, F., Nwose, O. M. and Mikhailidis, D. P. (1995) Gammaglutamyl transferase activity in human platelets. Quantification of activity, isoenzyme characterization and potential clinical relevance. Platelets 6, 200-203.

Karp, D. R., Carlisle, M. L., Mobley, A. B., Nichols, T. C., Oppenheimer-Marks, N., Brezýnschek, R. I. and Holers, M. V. (1999) $\gamma$-glutamyl transpeptidase is up-regulated on memory $\mathrm{T}$ lymphocytes. Int. Immunol. 11, 1791-1800.

Karp, D. R., Shimooku, K. and Lipsky, P. E. (2001) Expression of gglutamyl transpeptidase protecs ramos B cells from oxidationinduced cell death. J. Biol. Chem. 276, 3798-3804.

Khalaf, M. R. and Hayhoe F. G. J. (1987) Cytochemistry of gamma-glutamyl transferase in haemic cells and malignancies. Histochem. J. 19, 385-395.

Marathe, G. V., Damle, N. S., Haschemeyer, R. H. and Tate, S. S. (1980) Localization of $\gamma$-glutamyl transpeptidase in lymphoid cells. FEBS Lett. 115, 273-277.

Meister, A. (1973) On the enzymology of amino acid transport. Transport in kidney on probably other tissues is mediated by a cycle of enzymic reactions involving glutathione. Science 180, 33-39.

Meister, A. and Anderson, M. E. (1983) Glutathione. Аnпи. Rev. Biochem. 52, 711-760.

Morris, C., Courtay, C., Geurts-van Kessel, A., ten Hoeve, J., Heisterkamp, N. and Groffen, J. (1993) Localization of $\gamma$ glutamyl transferase related gene family on chromosome 22 . Hum. Genet. 91, 31-36.

Nemesanzky, E. and Lott, J. A. (1985) Gamma-glutamyl transferase and its isoenzymes: progres and problems. Clin. Chem. 31, 797-803.

Novogrosdky, A., Tate, S. S. and Meister, A. (1976) Gammaglutamyltranspeptidase, a lymphoid cell-surface marker: relation to blastogenesis, differentiation, and neoplasia. Proc. Natl. Acad Sci. USA 73, 2414-2418.

Pace-Asciak, C. R., Klein, J. and Spielberg, S. P. (1986) Metabolism of leukotriene $\mathrm{A}_{4}$ to $\mathrm{C}_{4}$ by human platelets. Biochim. Biopphys. Acta 877, 68-74.

Pawlak, A., Lahuna, O. and Bulle, F. (1998) Gamma-glutamyl transpeptidase a single copy gene in the rat a multiigene family in human genome. J. Biol. Chem. 263, 9913-9916.

Rosalki, S. B. and Tarlow, D. (1974) Optimized determination of $\gamma$-glutamyl transferase by reaction-rate analysis. Clin. Chem. 20, 1121-1124.

Russo, S. A., Harris, M. B. and Greengard, O. (1987) Diminished 
lymphocyte and granulocyte gamma-glutamyltranspeptidase activity in acute lymphocytic leukemia and response to chemotherapy. Am. J. Hematol. 26, 67-75.

Selvaraj, P. and Balasubramanian, K. A. (1982) Localization of $\gamma$ glutamyltransferase on polyacrylamide gel using L- $\gamma$-glutamyl p-nitroanilide as substrate. Clin. Chem. Acta 121, 291-308.

Shaw, L. M., London, J. W. and Petersen, L. E. (1978) Isolation of $\gamma$-glutamyltransferase from human liver and comparison with the enzyme from human kidney. Clin Chem. 24, 905-915.

Szasz, G. (1969) A kinetic photometric method for serum $\gamma$ glutamyl transpeptidase. Clin. Chem. 15, 124-135.

Szmigielski, S., Litwin, J. and Zupanska, B. (1965) Histochemical demonstration of gamma glutamyl transpeptidase activity in bone marrow and blood cells. J. Clin. Pathol. 18, 244-246.

Sener, A. (1997) Gamma-glutamiltransferaz. Biyokimya Dergisi 22, 27-33.

Sener, A. and Yardimci, T. (2000) Lectin affinity chromatography and electrophoretic properties of human platelet gammaglutamyl transferase. Platelets 11, 325-330.

Tager, M., Ittenson, A., Franke, A., Frey, A., Gassen, H. G. and Ansorge S. (1995) Gamma-glutamyltranspeptidase cellular expression in populations of normal uman mononuclear cells and patients suffering from leukemias. Ann. Hematol. 70, 237-
242.

Tarachand, U. (1984) Purification and properties of $\gamma$-glutamyl transpeptidase from rat deciduoma. J. Appl. Biochem. 6, 278288.

Tate, S. S. and Meister, A. (1978) Serineborate complex as a transition state inhibitor of $\gamma$-glutamyl transpeptidase. Proc. Natl. Acad. Sci. 75, 4806-4809.

Yao, D. F., Huang, Z. W., Chen, S. Z., Huang, J. F., Lu, J. X., Xiao, M. B. and Meng, X. Y. (1998) Diagnosis of hepatocellular carcinoma by quantitative detection of hepatomaspecific bands of serum gamma-glutamyltransferase. Am. J. Clin. Pathol. 110, 743-749.

Yardimci, T., Yaman, A. and Ulutin, O. N. (1995) Characterization of platelet gamma-glutamyl transferase and its alteration in cases of atherosclerosis. Clin. Appl. Thrombosis/Hemostasis. 1, 103-113.

Vesely, J., Lisy, V. and Cernoch, M. (1985) Partial purification of $\gamma$-glutamyl transferase from human brain microvessels. Neurochem. Res. 10, 1325-1334.

Visvikis, A., Pawlak, A., Accaoui, M. J., Ichino, K., Leh, H., Guellan, G. and Wellman, M. (2001) Structure of the 5' sequences of the human gglutamyltransferase gene. Eur. J. Iochem. 286, 317-325. 